\title{
The Ocular Surface in Keratoconjunctivitis Sicca
}

\author{
A. J. BRON and L. S. MENGHER \\ Oxford
}

\begin{abstract}
Summary
The ocular surface is altered in kerato-conjunctivitis sicca, a disorder of aqueous tear production. Many of the factors leading to these surface changes are now more clearly understood and are discussed in this paper.
\end{abstract}

\section{The Epithelium of the Normal Ocular Surface}

The surface epithelial cells of the cornea and conjunctiva exhibit delicate microvilli. In the conjunctiva they are coated with a glycocalyx which is in continuity with glycoprotein secreted into subsurface vesicles. ${ }^{1.2}$ This glycocalyx interacts with tear mucin histochemically stainable at the surface of the eye, whose precise disposition in vivo is not yet known.

Goblet cell distribution is not uniform across the globe and tarsus. Cell density is greater infranasally on the globe and is greatest on the caruncle. Cell density peaks shortly after birth and plateaus between the fourth and eighth decade. ${ }^{3}$ Goblet cells are absent from the limbus.

Inflammatory cells are present in the normal conjunctival epithelium and substantia propria, with neutrophils and lymphocytes in the epithelium and with neutrophils, lymphocytes, plasma cells and mast cells in the substantia propria ${ }^{4}$ Normal tears collected by micropipettes from the marginal strip are usually free of inflammatory cells; tears sucked from the bulbar surface do contain granulocytes. ${ }^{5,6,7}$

Vitamin A is essential to the maintenance of the normal architecture of the surface epithelia of the eye. As in other tissue it is assumed in the conjunctiva, a vascular tissue, that retinol is transferred from plasma retinol binding protein ( $\mathrm{pRBP}$ ) to a cellular retinol binding protein (cRBP). The corneal epithelium is denied a direct vascular source and it is likely that this is supplied by the tears, which contain less than $0.4-10.6 \mathrm{ng} / \mathrm{ml} .^{8}$ Recently it has been proposed that tearspecific prealbumin may play the role as a carrier for retinol in the tears, similar to that of RBP in the plasma. ${ }^{9}$ Tseng et al. in 1985 have suggested on the basis of transdifferentiation experiments that the degree of vascularisation of the ocular surface influences goblet cell density by modulating the delivery of retinol. ${ }^{10}$ If rabbit cornea including the limbus, is denuded of epithelium it is resurfaced by conjunctival epithelial cells which at first retain their biochemical and morphological features, including goblet cells. After a matter of weeks however they transdifferentiate and take on the appearance of corneal epithelial cells; the goblet cells are lost. ${ }^{11}$ This process of transdifferentiation can be prevented by topical treatment with retinoids ${ }^{12,13}$ or if the cornea which is resurfaced is vascularised (and therefore, it is presumed, provided with a source of retinol).

Tseng et al. have also suggested that scarring may diminish conjunctival vascularity in various forms of dry eye and contribute to the accompanying squamous metaplasia of the ocular surface. ${ }^{10}$ The alternative view has been proposed, that hyperosmolarity (vide infra) may be the cause of metaplasia, includ- 
ing goblet cell loss. ${ }^{14,15}$ This may be true but it must be noted that in animal models in which the lacrimal excretory duct is occluded, this would let tear retinol as well as lead to hyperosmolarity.

\section{Tear Mucin}

The goblet cells are assumed to be the major source of tear mucin (i.e. mucous glycoprotein). There is immunoidentity between at least one mucin fraction of the tears and a component of conjunctival goblet cell secretion. ${ }^{16}$ No such immunoidentity was found between tear mucin and lacrimal secretory acini. Huang et al. in 1987 have confirmed this in the rabbit using antibody against the core protein of a mucin fraction. ${ }^{17}$

\section{Viscosity of the Tears}

Mucus is responsible for the high viscosity of the tears and their non-Newtonian or pseudoplastic behaviour, that is, their viscosity is shear-dependent and they exhibit a fall in viscosity, at high shear rates ('shear thinning'). ${ }^{18}$ This property is thought to confer the advantage of low viscosity during a blink or saccade and stability of the tear film when the eye is stationary, for example, during fixation. ${ }^{19,20}$

During reflex tearing in normal subjects tear viscosity falls, which supports the view that the lacrimal gland is at least not the major source of tear mucin. The paper by Allen et al. (1972) identified the presence of glycoprotein within storage granules of human lacrimal gland. However, although this was taken to be mucus glycoprotein at the time, the histochemical techniques used are not able to distinguish between mucus and other types of glycoprotein..$^{21}$

\section{Wetting of the Ocular Surface}

Holly and Lemp in 1971 proposed that the corneal surface was non-wettable (hydrophobic) in vivo and that tear mucus served the role of rendering the epithelium hydrophilic. ${ }^{22}$ This conclusion was based on studies in which surface mucus was removed by gentle wiping or by chemical treatment. The corneal surface was found in these circumstances to become hydrophobic and the addition of mucus restored the normal hydrophilic properties of the corneal surface by lowering the surface tension. Recent studies by Cope et al. (1986) attempting to reproduce the conditions of these experiments, have shown that physical and chemical treatment of the corneal epithelium causes significant surface damage as demonstrated by scanning electron microscopy (SEM). ${ }^{23}$ Thus the hydrophobic behaviour of the cornea under these conditions may not reflect the native state of the epithelium in the absence of mucin. Preliminary studies by Tiffany have suggested that the native surface tension of the corneal epithelium, after removal of mucin by mild saline washing is low, that is, it is a wettable, hydrophilic surface. ${ }^{24}$

Holly has also proposed that dry spots would be initiated in dry eye by contamination of the epithelial surface by meibomian lipid. Mucin is envisaged as interacting with such lipid to prevent dry spots forming in this way. On these grounds mucin deficiency would encourage tear film instability. ${ }^{25}$

If tear mucin is not essential to render the corneal or indeed the conjunctival surface wettable, studies which correlate a loss of goblet cells with a reduction in tear stability must be interpreted with caution. If it is naturally wettable, then early tear break up in the presence of reduced goblet cell destiny may still imply the occurrence of a surface change in KCS which renders it hydrophobic; the 'lipid trapping' role for mucin may prove to be more tenable than a primary role in maintaining a hydrophilic epithelium (see below). Another possibility would be that loss of tear mucin reduces stability by lowering tear viscosity, since Benedetto et al. in 1975 demonstrated a relationship between viscosity of polymers used as tear substitutes and the thickness of the film formed. ${ }^{26}$

\section{Changes in the Tears and Ocular Surface in Kerato-conjunctivitis Sicca}

Infiltration of the lacrimal gland with round cells occurs in KCS and is assoicated with acinar atrophy ${ }^{27}$ and reduced secretion of lacrimal fluid ${ }^{28}$. This is the primary event from which most if not all changes at the ocular surface follow.

Many of the features of KCS are quantifiable (Table I), but only a small number of 
Table I

A. Aqueous deficiency

$\star$ Flow

$\star$ Volume

$\star$ Osmolarity

B. Mucin deficiency

$\star$ Goblet cell loss

$\star$ Lowered viscosity

$\star$ Increased surface tension

$\star$ Altered tear stability

$\star$ Altered mucus ferning

C. Lipid deficiency

$\star$ Fatty acid changes

$\star$ Interference microscopy

$\star$ Meibomian morphology

D. Chemical changes

$\star$ e.g. Lysozyme, lactoferrin, ceruloplasmin

E. Surface cellular damage

$\star$ e.g. Fluorescein, Rose Bengal staining

F. Inflammation

$\star$ Polymorphonuclear leucocytes

$\star$ Prostaglandins

$\star$ Superoxide

assessable features have been assessed as diagnostic tests.

It can be seen from the study of Van Bijsterveld (1969) that the Schirmer test has a high sensitivity ( $85 \%)$ and specificity $(83 \%)$ using a value of $<6 \mathrm{~mm}$ wetting as a cut off in the diagnosis of KCS. ${ }^{29}$ Farris et al. in 1983 not unexpectedly found a much lower sensitivity using a cut off of $3.5 \mathrm{~mm}$ wetting or less (Table II). ${ }^{30}$

Decreased flow is associated with decreased tear volume ${ }^{28,31}$ and a decreased height of the tear meniscus ${ }^{32,33}$ The meniscus height is not correlated with the Schirmer value in normal subjects. Only $7 \%$ of the normal subjects show a meniscus height of less than $0.1 \mathrm{~mm} \cdot{ }^{34}$ Continued evaporation from a preocular tear film of reduced volume leads to hyperconcentration of the tears. A rise in tear osmolarity was anticipated by von Bahr in 1941 and later confirmed by Mastmann et al. in 1961 and Mishima et al. in 1971. 35,36,28

Gilbard et al., (1978) using a micropipetting technique and a depression of freezing point method to determine osmolarity, found the osmolarity of normal tears to be $302 \pm 6.3 \mathrm{mOsm} / \mathrm{L}$ while that in a group of patients with $\mathrm{KCS}$ was considerably higher, $343 \pm 32.3 \mathrm{mOsm} / \mathrm{L} .{ }^{37}$ Farris et al. in 1983 using a cut off value of $>312 \mathrm{mOsm} / \mathrm{L}$ have found that the test has a sensitivity of $76 \%$ and a specificity of $84 \% .{ }^{30}$ Further studies by this group have shown hyperosmolarity in the range encountered in $\mathrm{KCS}$ to be damaging to rabbit corneal epithelial cells in vitro and hyperosmolarity has been suggested as the basis of ocular surface damage in KCS. ${ }^{38.39} \mathrm{We}$ have confirmed a rise in marginal strip osmolarity in KCS. ${ }^{5}$ Damage to the ocular surface is detected clinically by staining with fluorescein, which demonstrates corneal staining most effectively, or by Bengal Rose which demonstrates conjunctival surface damage better than corneal epithelial damage. However, Bengal Rose is poorly tolerated by KCS patients because of its low $\mathrm{pH}$ and the inability to wash away the compound with time following instillation. Fluorescein can be used to show conjunctival damage more effectively if the fluorescein is viewed

Table II Diagnostic tests of dry eye

\begin{tabular}{|c|c|c|c|c|}
\hline Test & Cut off & $\begin{array}{l}\text { Sensitivity } \\
\text { (per cent) }\end{array}$ & $\begin{array}{l}\text { Specificity } \\
\text { (per cent) }\end{array}$ & \\
\hline Schirmer $^{1}$ & $<3 \mathrm{~mm}$ & 10 & 100 & Flow \\
\hline Schirmer ${ }^{2}$ & $<6 \mathrm{~mm}$ & 85 & 83 & \\
\hline Rose Bengal ${ }^{1}$ & $<4$ & 58 & 100 & Damage \\
\hline Rose Bengal $^{2}$ & $<4$ & 95 & 96 & \\
\hline Basal tear vol.' & 104 & 59 & 77 & Volume \\
\hline Osmolarity ${ }^{1}$ & $312 \mathrm{mOsm} / \mathrm{L}$ & 76 & 84 & Evaporation \\
\hline Nibut $^{3}$ & $<10$ sec & 83 & 85 & Stability \\
\hline Lysozyme: mg1 & 110 & 67 & 67 & \\
\hline Lysozyme: ( $\left.{ }^{2} \mathrm{Dia}\right)$ & $<21 \mathrm{~mm}$ & 99 & 99 & \\
\hline
\end{tabular}

${ }^{1}$ Farris et al. 1983; ${ }^{2}$ Bijsterveld 1969; ${ }^{3}$ Mengher et al. 1986. 


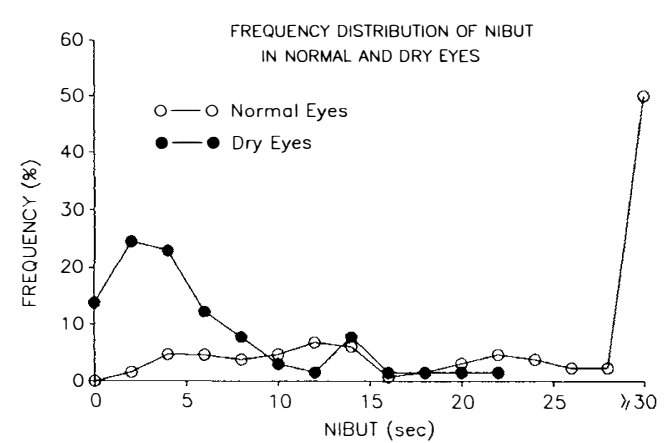

Fig. 1. Frequency distribution (\%) of non-invasive tear film break-up time (sec) in normal and dry eyes. (Mengher 1989)

through a yellow filter and a reasonable correlation is obtained if conjunctival staining assessed by Bengal Rose is compared with that demonstrated by fluorescein viewed in this way. ${ }^{40}$

Van Bijsterveld in 1969 devised a scoring system for Bengal Rose staining, with a score of $0-3$ for each interpalpebral conjunctival zone and for the cornea itself, to give a maximum aggregate of nine. ${ }^{29}$ Using a cut off value of $>3.5$ the test had a sensitivity of $95 \%$ and a specificity of $96 \%$. Farris et al. in 1983 in a similar study found a sensitivity of $58 \%$ and specificity of $100 \%$. $^{100}$

Van Bijsterveld further explored the diagnostic value of measuring tear lysozyme, recognising that lysozyme levels fell early in KCS and Sjögren's syndrome. Using a cut off value of $21.5 \mathrm{~mm}$ lysis, this test was found to have the greatest ability to discriminate between normals and dry eye patients, with a sensitivity of $99 \%$ and a specificity of $99 \% .^{29}$ The value obtained by Farris et al. ${ }^{30}$ is shown in Table II. Lactoferrin, another protein of lacrimal gland origin, also shows reduced tear levels in KCS. ${ }^{41}$ Mackie and Seal in 1984 have demonstrated the diagnostic value of this measurement as well as that of lysozyme when values are compared with age matched norms. ${ }^{42}$

Assessment of tear film stability by tear film break-up after the instillation of fluorescein, was introduced by Norn ${ }^{43}$ and by Lemp et al. ${ }^{44}$ and has become known by the name of break up time (BUT). Lemp and Hamill in 1973 advocated a cut off value of $<10$ seconds in the diagnosis of mucus deficiency. ${ }^{45}$ Although the BUT test has been criticised on the basis of its variability in normal subjects ${ }^{46}$ its repeatability in KCS patients does not appear to have been studied and the test is still held by us to be of value in patients with dry eye.

In 1983, in conjunction with Tonge and Gilbert of Smith and Nephew Pharmaceutical Research we devised a non-invasive tear break up test for clinical use in which break-up of a grid projected on the surface of the preocular tear film is observed by specular reflection. ${ }^{47}$ We confirmed that tear stability varies widely in normal subjects but found that variation is greatly reduced in dry eye patients. When a cut off of $<10$ seconds was used to discriminate normals from those with dry eye, the sensitivity of the test was $82 \%$ and the specificity $86 \% .^{48}$ (Fig. 1).

There are many events which occur at the ocular surface in KCS and which have been quantified, but for which sensitivity and specificity information is lacking.

(1) There is an increase in tear proteins of plasma origin, such as albumin ${ }^{5}$ and caeruloplasmin, due to an increase in capillary permeability presumably of conjunctival vessels (Fig. 2) although it is not excluded that permeability of lacrimal gland vessels is affected also. Since conjunctival capillaries are fenestrated and would be expected to leak protein anyway, it must also be considered whether conjunctival epithelial permeability increases also.

(2) There is an increased desquamation of

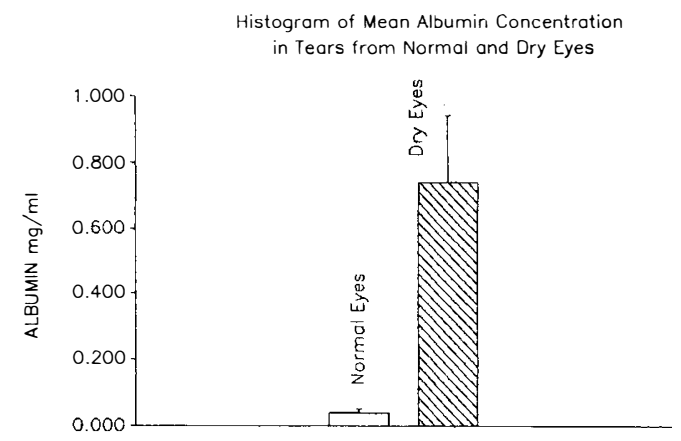

Fig. 2. Histogram of the concentration of albumin (mean \pm s.e.m) in tears from normal and dry eyes. (Mengher 1989) 
Table III White cell invasion of the tear fluid

\begin{tabular}{|c|c|c|c|c|c|}
\hline$K C S$ & Eye & $P M N / \mu l$ & Epith $/ \mu l$ & $\begin{array}{c}\text { Grade of } \\
\text { bulb conj. } \\
\text { injection }\end{array}$ & Remarks \\
\hline 1 & L.E. & 12,555 & 45 & +++ & Corneal ulcer \\
\hline 2 & L.E. & 2,385 & 270 & +++ & \\
\hline 3 & L.E. & 600 & 105 & + & Young epith cells \\
\hline 4 & R.E. & 605 & 55 & + & Young epith cells \\
\hline 5 & L.E. & 55 & 770 & + & Young epith cells \\
\hline 6 & R.E. & 55 & 1,155 & + & Young epith cells \\
\hline 7 & R.E. & 45 & 195 & + & Young epith cells \\
\hline 8 & L.E. & 15 & 930 & + & Young epith cells \\
\hline
\end{tabular}

epithelial cells into the conjunctival sac, related to the occurrence of squamous metaplasia and the increased stratification and separation of the epithelial cell layers noted for instance in the conjunctiva. ${ }^{49,6}$

(3) White blood cells, chiefly granulocytes, appear in the tears in KCS, sometimes in large numbers (Table III). ${ }^{5}$

(4) Tear viscosity falls in KCS and the tears appear to become more Newtonian in behaviour, that is their viscosity is less dependent on shear rate (Fig. 3 ). ${ }^{5}$ If this is correct, it would imply a diminished mucus content in the tears. However, because of the extended period in dry eye patients over which tears must be collected in sufficient volume to conduct viscosity measurements, the possibility of reflex dilution does arise. Confirmation must await the development of micromethods of viscosity measurement.

(5) Tear surface tension, measured by two microvolume techniques, either a hanging drop method ${ }^{5}$ or a capillary method ${ }^{50}$ is found to rise in KCS, again suggesting that tear mucus content is reduced (Fig. 4). This is supported by a negative correlation between tear viscosity and NIBUT (Fig. 5).

Since Norn, ${ }^{51}$ in other studies found an increased mucus production in KCS, it must be inferred that mucus, apparently present in such excess, is qualitatively different from that which confers viscous properties on the normal tears.

\section{Surface Morphology}

(6) Changes in the corneal surface have recently been detected by specular microscopy. Lemp and Gold in 1985 reported a decrease in corneal epithelial cell diameter and suggested that it might reflect an increased epithelial cell turnover. ${ }^{52}$

(7) In the conjunctiva the changes which occur are embodied in the term squamous metaplasia, ${ }^{53}$ with goblet cell loss ${ }^{54,55,56,57,58}$ enlargement of non-goblet epithelial cells $^{56,53}$ increased cellular stratification, ${ }^{49}$ keratinisation $^{60}$ and loss of surface microvilli. ${ }^{49}$

(a) Ralph in 1975 found a normal value of $8.84 \pm 4.66$ goblet cells $/ \mathrm{mm}$ of conjunctiva, based on biopsies in the inferior nasal fornix. ${ }^{55}$ The density of goblet cells was significantly less in KCS $(2.11 \pm 0.78 ; \quad P=0.001)$, Stevens-Johnson syndrome $(0.81 \pm$ 0.75), Ocular pemphigoid (0.33 \pm $0.37)$ and in acute alkali burns $(0.00) .{ }^{55}$

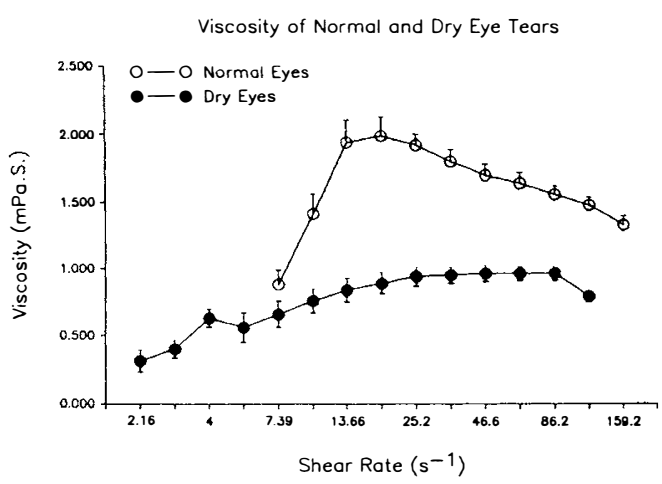

Fig. 3. Shows the viscosity of normal and dry eye tears over a range of shear rates. Each point represents a mean \pm s.e.m. (Mengher 1989) 


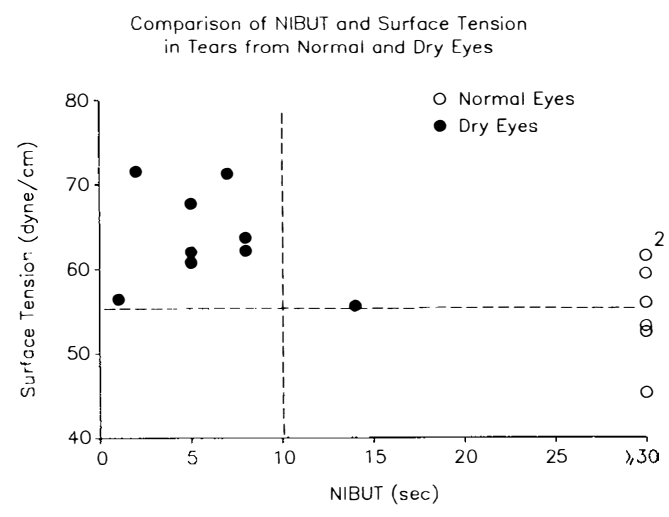

Fig. 4. Comparison of the non-invasive tear film break-up time and tear surface tension in normal and dry eyes. (Mengher 1989)

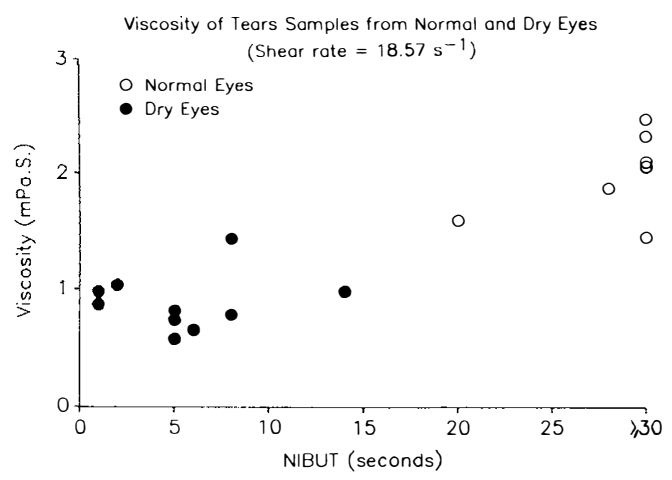

Fig. 5. Comparison of non-invasive tear film break-up time and tear viscosity in normal and dry eyes at a specified shear rate of $18.57 \mathrm{~s}^{-1}$. (Mengher 1989)

(b) Egbert et al. in 1977 reported their technique of impression cytology for the study of conjunctival epithelial morphology. In this technique, a strip of cellulose acetate paper is pressed against the ocular surface, fixed and stained with such stains as $\mathrm{H} \& \mathrm{E} /$ PAS or PAS/ Papanicolaou to demonstrate goblet cells and epithelial cells. ${ }^{61}$

Nelson, ${ }^{62}$ has standardised the technique using an ophthalmodynamometer to control the force of application and has devised a grading system involving the measurement of average epithelial cell area and goblet cell density using a calibrated microscope graticule. In grades $0-1$, mean individual cell area is less than $1000 \mu \mathrm{m}^{2}$ and the cells are round or slightly polygonal, with a nucleus to cytoplasm ratio of $1: 2$ to $1: 3$. Goblet cell density is greater than 350 cells $/ \mathrm{mm} .^{2}$ In grades 2 and 3 there is progressive enlargement of the epithelial cells (mean individual cell area: MICA) to $>1000 \mu \mathrm{m}^{2}$ and the cells are polygonal. Goblet cell density falls to $<100$ cells $/ \mathrm{mm} .{ }^{2}$ Grades 2 and 3 are regarded as abnormal and are found increasingly in KCS with the higher grades said to be associated with more severe disease (Table III). The grade does not however, correlate with either Schirmer test or Bengal Rose staining.

Nelson and Wright, ${ }^{57}$ confirmed the loss of goblet cells in KCS, Stevens-Johnson syndrome and pemphigoid reported by Ralph in $1975 .{ }^{55}$ They emphasise that in KCS uncomplicated by blepharitis or drug toxicity the fall in goblet cell density in the interpalpebral conjunctiva $(77 \%)$ precedes that in the inferior tarsal conjunctiva $(60 \%)$ whereas in pemphigoid and Stevens-Johnson syndrome there is major goblet cell loss in both zones.

Tseng et al. ${ }^{10}$ have postulated that the fall in goblet cell density in KCS may be due to a diminution of conjunctival vascularity due to scarring, and a consequent reduction in the delivery of vitamin $A$ to the conjunctiva. It is difficult to accept this as a mechanism in KCS since

Table IV Grading impression cytology

\begin{tabular}{lcccc}
\hline Grade & 0 & 1 & 2 & 3 \\
Cell shape & Small, round & & $1: 4-1: 5$ & Polygonal \\
NUC/CYT ratio & $1: 2$ & $1: 3$ & $>1: 6$ & $>1,000 \mu \mathrm{m}^{2}$ \\
Mean indiv. area & $<1,000 \mu \mathrm{m}^{2}$ & & & $<100$ \\
Goblet cell density/mm & $>500$ & $>350-500$ & $>100-350$ & \\
\hline
\end{tabular}

After Nelson and Wright 1984. 
clinically visible scarring would be unusual. Impression cytology has been used effectively in the study of xerophthalmia. Using the more extended grading scheme (0-5) devised by Tseng $e t$ al. ${ }^{10}$ Wittpenn et al. ${ }^{63}$ in a study of children in Madurai, India, found that all children with early xerophthalmia showed complete goblet cell loss and the appearance of enlarged, partially keratinised cells. Biopsies from treated and normal children showed normal goblet and non-goblet epithelial cells. In a subsequent study in Indonesia, taking the lowest grade from an individual eye, it was found that a grade of 0 or 1 was consistent with a serum retinol level of greater than or equal to $0.70 \mathrm{~mol} / \mathrm{L}(20 \mathrm{~g} / \mathrm{dL})$ while a grade of $2-5$ signified a retinol level below this, which was regarded as abnormal. In a study of 75 pre-school children with mild xerophthalmia and 74 neighbourhood, age-matched clinically normal controls, impression cytology was closely correlated with baseline serum vitamin A levels. Subclinical vitamin A deficiency was detected in $23 \%$ (14 out of 60 ) of the control population: treatment of both groups with vitamin A capsules resulted in improvement in the cytology grade in $95 \%$ of those with originally abnormal grades. ${ }^{64}$

The value of impression cytology in diagnosing vitamin A deficiency, particularly in its subclinical form arises not only from its implications for blindness but also from the observation that vitamin $\mathrm{A}$ deficiency is associated with an increased morbidity and mortality. ${ }^{65,66,67,68}$ Vitamin A supplementation of xerophthalmic, but also non-xerophthalmic children from the same region reduces mortality, suggesting

Table V Snake-like chromatin

\begin{tabular}{lcc}
\hline & Per cent & $(n)$ \\
\hline Normals & 1.3 & 300 \\
$1^{\circ}$ and $2^{\circ}$ Sjögrens & 57.1 & 14 \\
KCS & 40.0 & 30 \\
Contact Lens & 39.6 & 48 \\
\hline
\end{tabular}

After Kruse etal. 1986.

\section{Table VI Natural history of KCS}

1. Lacrimal inflammation and atrophy leads to-

2. Reduced tear flow, volume, thickness, lubrication

3. Increased tear osmolarity and altered salt concentration, causes-

4. Ocular surface damage with squamous metaplasia, directly or secondary to vitamin A deficiency

5. Inflammation supervenes with hyperaemia, tear white cell invasion and Meibomitis

6. Secondary interactions exacerbate these events

that benefit is conferred on those with subclinical as well as clinically evident disease.

(8) An intriguing conjunctival sign demonstrated by impression cytology in $\mathrm{KCS}$ is the 'snake-like chromatin' pattern observed by Marner ${ }^{69,70}$ in $25 \%$ of patients with suspected Sjögren's syndrome and $50 \%$ of patients with chronic KCS. The pattern consists of a sinous condensation of the nuclear chromatin and is found preferentially over the upper bulbar conjunctiva. ${ }^{70}$ The presence of 'snake-like chromatin' pattern correlated with the severity of the disease as measured by BUT, Bengal Rose staining and Schirmer's test.

The pattern is however, not specific to $\mathrm{KCS}$, and is found for example in allergic conjunctivitis $^{69}$ and in contact lens wearers, but rarely in normal subjects (five out of 300). ${ }^{71}$ It has been suggested that it represents a non-specific response to trauma. Curiously it has not been demonstrated in cells removed by conjunctival scraping ${ }^{69}$ (Table V).

\section{Conclusions}

Based on our current understanding of the disease, the natural history of KCS may be hypothesised as follows (Table VI):

Reduced tear flow leads to reduced tear volume and an increased osmolarity of the tears. Increased osmolarity damages the ocular surface, detected as punctate surface staining. A fall in goblet cell density may be related to hyperosmolarity or to a reduced delivery of vitamin A (retinol) to the conjunctiva via conjunctival vessels. But an additional possibility is that tear retinol levels or 
tear carrier protein levels are reduced due directly to lacrimal gland damage.

In keeping with the reduced goblet cell density there is an altered physical behaviour of the tears with a reduction in viscosity, rise in surface tension and loss of tear stability as measured by BUT and NIBUT. The surface of conjunctival epithelial cells increase in area while those of the cornea decrease. It is not possible to explain both events by a single mechanism, but possibly there is a reduced limbal contribution to corneal epithelial cells.

Damage to the ocular surface stimulates a white cell response and white cells may release mediators (PGE2) and active oxygen species (superoxide) which may themselves damage the ocular surface. The ability of the tears to buffer these effects may be reduced by a loss of scavenger molecules. So far no information is available as to whether the primary change occurring in ocular surface epithelium is similar to those affectng the lacrimal gland itself.

\section{References}

${ }^{1}$ Dilly PN and Mackie IA: Surface changes in the anaesthetic conjunctiva in man with special reference to the production of mucus from a nongoblet cell source. Br J Ophthalmol 1981, 65: 83342.

2 Dilly PN: Contribution of the epithelium to the stability of the tear film. Trans Ophthalmol Soc UK 1985, 104: 381-9.

${ }^{3}$ Kessing SV: Mucous gland system of the conjunctiva. A quantitative normal anatomical study. Acta Ophthalmol 1968, 95: 1-33.

${ }^{4}$ Allansmith MR, Greiner JV, Baird RS: Number of inflammatory cells in the normal conjunctiva. Am J Ophthalmol 1978, 86: 250-9.

${ }^{5}$ Mengher LS: Tear assessment in the dry eye. D Phil Thesis. In preparation. University of Oxford.

${ }^{6}$ Bron AJ, Mengher LS, Davey CC: The normal conjunctiva and its response to inflammation. Trans Ophthalmol Soc UK 1985, 104: 424-35.

${ }^{7}$ Norn MS: Conjunctivo-cytologic studies. In External Eye. Methods of Examination. Copenhagen. Scriptor. 1974, 142-64.

${ }^{8}$ Speek AJ, van Agtmaal EJ, Saowakontha S, Schreurs WHP, van Haeringen NJ: Fluorometric determination or retinol in human tear fluid using high performance liquid chromatography. Curr. Eye Res 1986, 5: 841-5.

${ }^{9} \mathrm{Chao} \mathrm{CCW}$ and Butala SM: Isolation and preliminary characterisation of tear prealbumin from human ocular mucus. Curr Eye Res 1986, 5: 895 901.

10 Tseng SCG, Hirst LW, Farazdaghi M, Green WR: Goblet cell density and vascularization during conjunctival transdifferentiation. Invest Ophthalmol Vis Sci 1984, 25: 1168-76.

${ }^{11}$ Friedenwald JS: Growth pressure and metaplasia of conjunctival and corneal epithelium. Doc Ophthalmol 1951, 5-6: 184-90.

12 Tseng SCG, Hirst LW, Farazdaghi M, Maumenee AE, Green WR: Retardation of conjunctival trans-differentiation by topical retinoids (abstract-2) Invest Ophthalmol Vis Sci (suppl) 1984, 25: 76-8.

${ }^{13}$ Farazdaghi M, Liu SH, Rider AA, Lutty GA, Prendergast RA, Tseng SCG: Reversal of conjunctival trans-differentiation by retinoids (abstract-4). Invest Ophthalmol Vis Sci (suppl) 1984, 25: 76-8.

${ }^{14}$ Gilbard JP, Rossi SR, Gray KL: A new rabbit model for keratoconjunctivitis sicca. Invest Ophthalmol Vis Sci 1987, 28: 225-8.

${ }^{15}$ Gilbard JP, Rossi SR, Gray KL, Hanninen LA, Kenyon KR: Tear film osmolarity and ocular surface disease in two rabbit models for keratoconjunctivitis sicca. Invest Ophthalmol Vis Sci 1988 , 29: $374-8$.

${ }^{16}$ Moore JC and Tiffany JM: Human ocular mucus. Origins and preliminary characterisation. Exp Eye Res 1979, 29: 291-301

${ }^{17}$ Huang AJW and Tseng SCG: Development of monoclonal antibodies to rabbit ocular mucin Invest Ophthalmol Vis Sci 1987, 28: 1483-91.

${ }^{18}$ Kaura R and Tiffany JM: The role of mucus glycoproteins in the tear film. In: Holly FJ, ed. The preocular tear film in health, disease and contact lens wear. Lubbock, TX: Dry Eye Institute, 1986, 728-32.

${ }^{19}$ Hamano $\mathrm{H}$ and Kaufman HE: Physiology of the cornea and contact lens applications. Publisher Churchill-Livingstone, 1986.

${ }^{20}$ Bron AJ: Prospects for the dry eye. Duke-Elder lecture. Trans Ophthalmol Soc UK 1985, 104: 801-26.

${ }^{21}$ Allen M, Wright P, Reid L: The human lacrimal gland. A histochemical and organ culture study of the secretory cell. Arch Ophthalmol 1972, 88: 493-7.

22 Holly FJ and Lemp MA: Wettability and wetting of the corneal epithelium. Exp Eye Res 1971, 11: 239-50.

${ }^{23}$ Cope C, Dilly PN, Kaura R, Tiffany JM: Wettability of the corneal surface: a reappraisal. Curr Eye Res 1986, 5: 777-85

24 Tiffany JM: Measurement of wettability of the corneal surface (abstract). 28th meeting of the Association for Eye Research, Belgium. Sept. 16-19, 1987. Published in Ophthalmic Res 1988 20: 61-98.

${ }^{25}$ Holly FJ: Formation and stability of the tear film. Int Ophthalmol Clin 1973, 13: 73-96.

${ }^{26}$ Benedetto DA, Shah DO, Kaufman HE: The instilled fluid dynamics and surface chemistry of 
polymers in the pre-ocular tear film. Invest Ophthalmol 1975, 14: 887-92.

${ }^{27}$ Nasu M, Matsubara, Yamamoto H: Post-mortem prevalence of lymphocytic infiltration of the lacrimal gland: A comparative study in autoimmune and non-autoimmune diseases. J Pathol 1984, 143: $11-15$.

${ }^{28}$ Mishima S, Kubota Z, Farris RL: Tear flow dynamics in normal and in keratoconjunctivitis sicca cases: in Solanes MP, ed. XXI Concilium Ophthalmologicum, Mexico DF. 8-14 March 1970. Amsterdam. Excerpta Medica. 1971, part II: $1801-5$.

${ }^{29}$ van Bijesterveld OP: Diagnostic tests in sicca syndrome. Arch Ophthalmol 1969, 82: 10-14.

${ }^{30}$ Farris RL, Gilbard JP, Stuchell RN, Mandel ID: Diagnostic tests in keratoconjunctivitis sicca. TCLAO J 1983, 9: 23-8.

${ }^{31}$ Scherz W, Doane MG, Dohlman $\mathrm{CH}$ : Tear volume in normal eyes and keratoconjunctivitis sicca. Albrecht v. Graefes Arch Klin Exp Ophthamol 1974, 192: 151-60.

${ }^{32}$ Klein M: The lacrimal strip and precorneal tear film in cases of Sjögren's syndrome. Br J Ophthalmol 1949, 33: 387-8.

${ }^{33}$ Lamberts DW: Keratoconjunctivitis sicca. In Smolin G and Thoft RA, eds. The Cornea. Boston. Little Brown and Co 1987, 387-404.

${ }^{34}$ Lamberts DW, Foster CS, Perry HD: Schirmer test after topical anaesthetesia and tear meniscus height in normal eyes. Arch Ophthalmol 1979, 97: 1082-5.

${ }_{35}$ von Bahr G: Konnte der flussigkeitsabgang durch die cornea von physiologischer bedeutung sein? Acta Ophthalmol 1941, 19: 125-34.

${ }^{36}$ Mastmann GJ, Baldes EJ, Henderson JW: The total osmotic pressure of tears in normals and various pathological conditions. Arch Ophthalmol 1961, 61: $509-13$.

${ }^{37}$ Gilbard JP, Farris RL, Santamaria J: Osmolarity of tear microvolumes in keratoconjunctivitis sicca. Arch Ophthalmol 1978, 96: 677-81.

${ }^{38}$ Gilbard JP, Carter JB, Sang DN, Refojo MF, Hanninen LA, Kenyon KR: Morphologic effect of hyperosmolarity on rabbit corneal epithelium. Ophthalmol 1984, 91: 1205-12.

${ }^{39}$ Verges C, Refojo MF, Gilbard JP, Kenyon KR: Effect of hyperosmolarity on conjunctival goblet cells density in vivo (abstract 8) Invest Ophthalmol Vis Sci (suppl). 1984, 25: 190-2.

${ }^{40}$ Hardman-Lea S, Mengher LS, Davey CC, Bron AJ: Rose bengal and fluorescein staining in the assessment of keratoconjunctivitis sicca (abstract). 27th meeting of the Association for Eye Research. Oxford, England. Sept 14-18th 1986, Published in Ophthalmol Res 1987, 19: 19-20.

${ }^{41}$ Seal DV: The effect of ageing and disease on tear constituents. Trans Ophthalmol Soc UK 1985, 104: $355-62$.

42 Mackie IA and Seal DV: Diagnostic implications of tear protein profiles. Br J Ophthalmol 1984, 68: $321-4$.

${ }^{43}$ Norn MS: Desiccation of the precorneal film: I corneal wetting time. Acta Ophthalmol 1969, 47: 856-80.
${ }^{44}$ Lemp MA, Dohlman CH, Holly FJ: Corneal desiccation despite normal tear volume. Ann Ophthalmol 1970, 2: 258-84.

${ }^{45}$ Lemp MA and Hamill JR: Factors affecting tear film break up in normal eyes. Arch Ophthalmol 1973, 89: $103-5$.

46 Vanley GT, Leopold HI, Gregg TH: Interpretation of tear film break up. Arch Ophthalmol 1977, 95: 445-8.

${ }^{47}$ Mengher LS, Bron AJ, Tonge SR, Gilbert DJ: A non-invasive instrument for clinical assessment of the pre-corneal tear film stability. Curr Eye Res 1985, 4: 1-7.

${ }^{48}$ Mengher LS, Pandher KS, Bron AJ: Non-invasive tear film break up time; Sensitivity and Specificity Acta Ophthalmol 1986, 64: 441-4.

${ }^{49}$ Abdel-Khalek LMR, Williamson J, Lee WR: Morphological changes in the human conjunctival epithelium II. In keratoconjunctivitis sicca. $\mathrm{Br} J$ Ophthalmol 1978, 62: 800-6.

${ }^{50}$ Tiffany JM, Winter N, Bliss G: Tear film stability and tear surface tension. Curr Eye Res (submitted).

${ }^{51}$ Norn MS: Vital staining of cornea and conjunctiva. Acta Ophthalmol (suppl 113) 1972, 39-46.

${ }^{52}$ Lemp MA and Gold JB: An in vivo study of the corneal surface in keratoconjunctivitis sicca. Trans Ophthalmol Soc UK 1985, 104: 436-8.

${ }^{53}$ Sjögren $\mathrm{H}$ and Bloch $\mathrm{KJ}$ : Keratoconjunctivitis sicca and the Sjögren syndrome. Surv Ophthalmol 1971, 16: 145-59.

${ }^{54}$ Lemp MA, Dohalman CH, Kuwabra T, Holly FJ, Carroll JM: Dry eye secondary to mucus deficiency. Trans Am Acad Ophthalmol Otolarygol 1971, 1223-27.

${ }^{55}$ Ralph RA: Conjunctival goblet cell density in normal subjects and in dry eye syndromes. Invest Ophthalmol Vis Sci 1975, 14: 299-302.

${ }^{56}$ Nelson JD, Havener VR, Cameron JD: Cellulose acetate impressions of the ocular surface: Dry eye states. Arch Ophthalmol 1983, 101: 1869-72.

${ }^{57}$ Nelson JD and Wright JC: Conjunctival goblet cell densities in ocular surface disease. Arch Ophthalmol 1984, 102: 1049-51.

${ }^{58}$ Nelson JD and Wright JC: Impression cytology of the ocular surface in keratoconjunctivitis sicca. In: Holly FJ, ed. The preocular tear film in health, disease and contact lens wear. Lubbock TX: Dry Eye Institute, 1986, 140-56.

${ }^{59}$ Norn MS and Kristensen EB: Benign mucous membrane pemphigoid II. Cytology Acta Ophthalmol 1974, 52: 282-90.

${ }^{60}$ Maumenee AE: Keratitis secondary to keratinization of the tarsal conjunctiva. Am J Ophthalmol 1956, 41: 477-87.

${ }^{61}$ Egbert PR, Lauber MA, Maurice DM: A simple conjunctival biopsy. Am J Ophthalmol 1977, 84: 798-801.

62 Nelson JD: Impression cytology. Cornea 1988, 71-81.

${ }^{63}$ Wittpenn JR, Tseng SCG, Sommer A: Detection of early xerophthalmia by impression cytology Arch Ophthalmol 1986, 104: 237-9.

${ }^{64}$ Natadisastra G, Wittpenn JR, West KP, Muhilal $\mathrm{RD}$, Sommer A: Impression cytology for detection of vitamin A deficiency. Arch Ophthalmol 1987, 105: 1224-8. 
${ }^{65}$ Sommer A, Tarwotjo I, Hussaini G, Susanto D: Increased mortality in children with mild vitamin A deficiency. Lancet 1983, 2: 585-8.

${ }^{66}$ Sommer A: Mortality associated with mild, untreated xerophthalmia. Trans Am Ophthalmol Soc 1983, 81: 825-53.

${ }^{67}$ Sommer A, Katz J, Tarwotjo I: Increased risk of respiratory disease and diarrhea in children with pre-existing mild vitamin A deficiency Am J Clin Nutr 1984, 40: 1090-5.

${ }^{68}$ Sommer A, Tarwotjo I, Djunaedi E, West KP, Loeden A, Tilden R and The Aceh Study Group: Impact of vitamin A supplementation on childhood mortality. A randomised controlled community trial. Lancet 1986, 1: 1169-73.
${ }^{69}$ Marner K: 'Snake-like' appearance of nuclear chromatin in conjunctival epithelial cells from patients with keratoconjunctivitis sicca. Acta Ophthalmol 1980, 58: 849-53.

${ }^{70}$ Marner K, Manthrope R, Prause JU: Snake-like nuclear chromatin in imprints of conjunctival cells from patients with Sjögren's syndrome. In Machtey I, ed. Progress in Rheumatology. Rheumatology Service, Hasharon Hospital, PetanTiqva, Israel 1984, Vol. II, 127-30.

${ }^{71}$ Kruse FE, Jaeger W, Gotz ML, Schmitz W: Conjunctival morphology in Sjögren's syndrome and other disorders of the anterior eye. Scand J Rheumatol 1986 (suppl) 61, 206-14. 